\title{
Oral and cloacal aerobic bacterial and fungal flora of free-living four-lined snakes (Elaphe quatuorlineata) from Croatia
}

\author{
Maja Lukač ${ }^{1 *}$, Danijela Horvatek Tomić1, Zrinka Mandac², \\ Sanja Mihoković́ 3 , and Estella Prukner-Radovčić ${ }^{1}$ \\ ${ }^{I}$ Department of Poultry Diseases with Clinic, Faculty of Veterinary Medicine, University of Zagreb, \\ Zagreb, Croatia \\ ${ }^{2}$ Veterinary Outpatient Clinic "Ljubimac”, Zagreb, Croatia \\ ${ }^{3}$ PrimeVigilance, Zagreb, Croatia
}

LUKAČ, M., D. HORVATEK TOMIĆ, Z. MANDAC, S. MIHOKOVIĆ, E. PRUKNER-RADOVČIĆ: Oral and cloacal aerobic bacterial and fungal flora of free-living four-lined snakes (Elaphe quatuorlineata) from Croatia. Vet. arhiv 87, 351-361, 2017.

ABSTRACT

The aim of this study was to identify oral and cloacal aerobic flora of four-lined snakes (Elaphe quatuorlineata) from Croatian islands Cres and Olib to get better insight into bacteria and fungi potentially harmful to both the animals and the people getting in contact with those animals. Oral and cloacal swabs were taken from a total of 20 snakes and analyzed by standard microbiology and by Real-Time PCR method for Chlamydia spp. identification. Neither Salmonella spp. nor Chlamydia spp. were detected, but some potentially human pathogens, such as Aeromonas hydrophila, Escherichia coli, Serratia marcescens and Stenotrophomonas maltophilia, were isolated. Some of fungi detected, such as Candida albicans, Aspergillus flavus and Cladosporium sp., have already been described as secondary causative disease agents in reptile collections. To the author's knowledge this study is the first survey of aerobic microflora of four-lined snakes.

Key words: four-lined snakes, oral cavity, cloaca, bacteria, fungi

\section{Introduction}

Information related to gastrointestinal microflora of snakes is scarce. Most of the investigations studied bacteria from the oral cavity of venomous snakes and complications of snake bites (JHO et al., 2011; LIU et al., 2012). Non-venomous snakes may also harbor a wide range of bacteria in their oral cavity able to complicate the bite wounds (DIPINETO

\footnotetext{
*Corresponding author:

Dr. Maja Lukač, DVM, Department of Poultry Diseases with Clinic, Faculty of Veterinary Medicine, University of Zagreb, Heinzelova 55, 1000 Zagreb, Croatia, Phone: +385 12390 410; Fax: +385 12390 410; E-mail: maja.lukac@vef.hr
} 
et al., 2014; YAK et al., 2015) so the information on their microflora should not be neglected. Secondary bacterial infections, such as subcutaneous abscess or tetanus, are possible complications of snake bites, either venomous or non-venomous snakes (HABIB, 2002; GARG et al., 2009). In addition to bites, humans can be infected during manipulation of animals (RABINOWITZ et al., 2007; DEKKER and FRANK, 2015) or via infected equipment (FOSTER and KERR, 2005). The popularity of snakes as pets and the models of biological and veterinary research increased the risk for a public health due to the zoonotic potential of these animals.

Many fungal species were isolated from reptiles, including snakes (ROSENTHAL and MADER, 1996; NICHOLS et al., 1999; CHEATWOOD et al., 2003). Although most of the fungi are normal residents of reptile gastrointestinal tract, they can cause secondary infections under suboptimal conditions and can play an important role as disease-causing agents in reptiles including snakes (JACOBSON, 1980; HERNANDEZ-DIVERS, 2001; MILLER et al., 2004; OROS et al., 2004).

There is no information regarding microflora and potential pathogens from gastrointestinal system of Croatian autochthonous snakes. Therefore, oral cavity and cloacal swabs were taken from a total of 20 four-lined snakes (Elaphe quatuorlineata) at Croatian islands Cres and Olib, to get more insight into physiological microflora, potential pathogens and opportunistic organisms from oral cavity and cloaca of free-living snakes.

\section{Materials and methods}

Animals. A total of 20 four-lined snakes (Elaphe quatuorlineata) from islands Cres and Olib, 10 animals from each island, were sampled at their natural habitats. Biological characteristics and behavior of animals and their habitats are described in Table 1. All of the animals were captured during May and June 2013.

Capture and clinical examination. Animals were captured by hands, and manually restrained using leather gloves, at various locations of islands Cres $\left(44^{\circ} 57^{\prime} 36^{\prime \prime} \mathrm{N}\right.$,

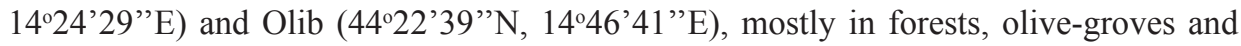
dry walls. Each animal was immediately examined by visual inspection of the eyes, nostrils, cloaca and skin. The complete body surface was also inspected for the presence of injuries or deformations. After opening by a sterile forceps, oral cavity was inspected for the presence of stomatitis or mechanical injuries.

Sampling. Following appropriate marking of swab tubes, the sampling was carried out as follows: one person fixed the snake's head, the other one opened its orifice laterally to avoid oral cavity injury and took two swabs from both cloaca and oral cavity (Figs. 1 and 2). Swabs taken with transport media (Amies transport swabs Aptaca, Italy) were used for standard microbiology, and those without transport media (Copan plain swab, Italy) were used for molecular diagnostic. The animals were then released at the sites of their capture. The swabs were stored at $4{ }^{\circ} \mathrm{C}$ until examination. 
M. Lukač et al.: Oral and cloacal aerobic microflora of four-lined snakes (Elaphe quatuorlineata) from Croatia

Table 1. Biological characteristics, behaviour and habitat description of captured four-lined snakes from islands Cres and Olib

\begin{tabular}{|c|c|c|c|c|}
\hline \multicolumn{5}{|c|}{ Island Cres } \\
\hline Age & Gender & Behaviour & Habitat description & No. \\
\hline Adult & Female & Resting in shade & Wood surrounded with dry walls & 1 \\
\hline Adult & Male & Resting in shade & Wood surrounded with dry walls & 2 \\
\hline Adult & Male & Basking & Open karst terrain with a little bit of vegetation & 1 \\
\hline Juvenile & Female & Basking & Open karst terrain with a little bit of vegetation & 1 \\
\hline Juvenile & Female & Resting in shade & Wood surrounded with dry walls & 2 \\
\hline Juvenile & Male & Basking & Open karst terrain with a little bit of vegetation & 3 \\
\hline \multicolumn{4}{|l|}{ Total } & 10 \\
\hline \multicolumn{5}{|c|}{ Island Olib } \\
\hline Adult & Female & Basking & Macchia surrounded with dry walls & 1 \\
\hline Adult & Female & Basking & Karst terrain with a low vegetation & 1 \\
\hline Adult & Female & Basking & Holm oak wood surrounded with dry walls & 1 \\
\hline Adult & Male & Basking & Karst terrain with a low vegetation & 2 \\
\hline Adult & Male & Resting in shade & Bushes with rocks & 1 \\
\hline Subadult & Female & Basking & Holm oak wood surrounded with dry walls & 2 \\
\hline Subadult & Male & Hiding & Karst terrain with a low vegetation & 1 \\
\hline Subadult & Male & Escaping & Karst terrain with a low vegetation & 1 \\
\hline \multicolumn{4}{|l|}{ Total } & 10 \\
\hline
\end{tabular}

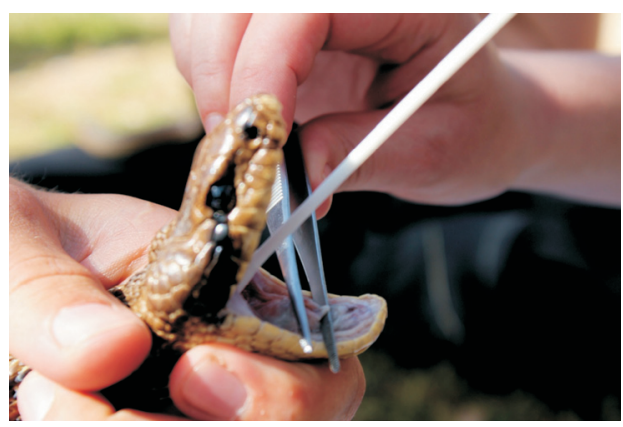

Fig. 1. Oral cavity swabbing of the four-lined snake

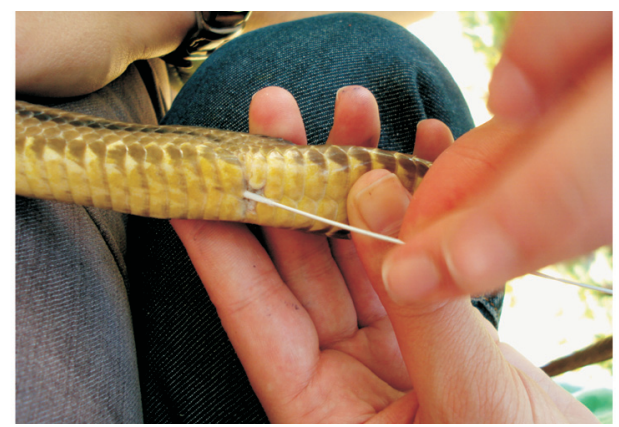

Fig. 2. Cloacal swabbing of the four-lined snake 
Microbiological procedures. The samples (40 in total) were processed in the bacteriological laboratory at the Department of Poultry Diseases with Clinic, Faculty of Veterinary Medicine, University of Zagreb. For aerobic bacteria identification standard methods described by BROWN (2005) were used. Samples were plated directly on the Nutrient agar (Difco Nutrient Agar, Becton, Dickinson and Company, SAD) and selective Brilliant green agar (BGA) (Brilliant green agar - modified, Oxoid, England) and incubated under aerobic conditions for $24 \mathrm{hrs}$ at room temperature. Results were read after 24 and 48 hrs, depending on the growth of bacterial colonies. Bacterial colonies were then randomly selected, recultivated to obtain the pure bacterial culture and examined microscopically after Gram-staining (Gramova otopina, Gram-Mol d.o.o., Croatia). Isolated bacteria were further identified morphologically, by oxidase (Oxidase strips, Oxoid, Great Britain) and catalase (vodikov peroksid, Kemika, Croatia) tests, and biochemically by the Analytical profile index (API) (API E and API NE System, Bio Merieux S.A., France). For fungal identification, swabs were plated on Sabouraud dextrose agar (Sabouraud dextrose agar, Oxoid, England) and incubated at room temperature for up to five days. Fungi were identified based on their morphological characteristics and microscopically by lactophenol staining (Lactophenol blue solution, Sigma-Aldrich, France).

Salmonella spp. detection. Cloacal swabs were enriched in Selenite cysteine broth (Becton-Dickinson and Company, France), incubated for $24 \mathrm{hrs}$ at $37{ }^{\circ} \mathrm{C}$, plated on BGA and Xylose lysine deoxycholate agar (XLD) (Merck, Germany), and incubated 24 hours at $37{ }^{\circ} \mathrm{C}$ and then $24 \mathrm{hrs}$ at room temperature.

Chlamydia spp. detection. Pooled samples of oral cavity and cloaca of each snake were analysed in the Laboratory for Chlamydia at the above Department. The DNA was extracted using GenElute Mammalian Genomic DNA Miniprep kit (Sigma-Aldrich, USA) according to the manufacturer's instructions and examined by Chlamydiaceae-specific Real-Time PCR described by EHRICHT et al. (2006). Each sample was run in duplicate, with positive (C. psittaci strain) and negative (ultrapure water) controls, also run in duplicate. Samples were analysed by the Mx3005P (Stratagene, USA) instrument with TaqMan system for replicated segments identification under the following conditions: 95 ${ }^{\circ} \mathrm{C} 10 \mathrm{~min}, 50$ replication cycles, denaturation for $15 \mathrm{sec}$ at $95^{\circ} \mathrm{C}$, primer annealing at 60 ${ }^{\circ} \mathrm{C}$ for $60 \mathrm{sec}$, when fluorescence was recorded.

Statistics. The results were analysed by the Fischer's exact test using MedCalc, version 10.4.0.0., MedCalc Software bvba, Mariakerke, Belgium.

\section{Results}

Clinical examination did not reveal any deformations or pathological changes on animal's eyes, nostrils or skin. The oral cavities of all animals were clean and free of any pathological changes. 
M. Lukač et al.: Oral and cloacal aerobic microflora of four-lined snakes (Elaphe quatuorlineata) from Croatia

Oral and cloacal aerobic flora was analyzed in a total of 20 four-lined snakes from Croatian islands Cres and Olib. Bacteria and/or fungi were detected in cloacal swabs of all animals and in oral cavity swabs of eight animals from each island.

Table 2. Bacterial species isolated from oral cavity and cloaca of four-lined snakes from islands Cres and Olib

\begin{tabular}{|c|c|c|}
\hline \multirow[b]{2}{*}{ Bacterial species } & \multicolumn{2}{|c|}{ Number of positive findings in 10 animals from each island } \\
\hline & Cres & Olib \\
\hline & \multicolumn{2}{|c|}{ Oral cavity } \\
\hline Aeromonas hydrophila & 1 & \\
\hline Aeromonas salmonicida & 2 & 3 \\
\hline Escherichia coli & & $1^{\mathrm{B} * *}$ \\
\hline Proteus mirabilis & 1 & \\
\hline Pseudomonas fluorescens & 4 & 1 \\
\hline Serratia marcescens & 2 & \\
\hline Stenotrophomonas maltophilia & 3 & 1 \\
\hline Micrococcus luteus & & 1 \\
\hline Bacillus cereus & 2 & \\
\hline Bacillus sp. & 2 & 3 \\
\hline \multirow[t]{2}{*}{ Staphylococcus sp. } & 3 & 3 \\
\hline & \multicolumn{2}{|c|}{ Cloaca } \\
\hline Aeromonas hydrophila & 4 & \\
\hline Escherichia coli & 5 & $6^{\mathrm{A}}$ \\
\hline Pseudomonas fluorescens & 1 & \\
\hline Serratia marcescens & 1 & \\
\hline Stenotrophomonas maltophilia & 1 & \\
\hline Proteus sp. & $1^{a * *}$ & $9^{b}$ \\
\hline Bacillus cereus & 3 & \\
\hline Micrococcus luteus & 1 & \\
\hline Staphylococcus sp. & 1 & 1 \\
\hline Bacillus sp. & $8^{\text {a* }}$ & $1^{\mathrm{b}}$ \\
\hline
\end{tabular}

Different lowercase superscript letters indicate differences between Cres and Olib animals, while different uppercase superscript letters indicate difference between oral cavity and cloaca of the whole group of animals; $* \mathrm{P}=0.005, * * \mathrm{P}=0.001$ (Fischer's exact test). 
M. Lukač et al.: Oral and cloacal aerobic microflora of four-lined snakes (Elaphe quatuorlineata) from Croatia

Island Cres. Nine bacterial species, belonging to Gram-positive and Gram-negative flora, were identified in the oral cavity. The most represented species was Pseudomonas fluorescens, followed by Staphylococcus sp., Stenotrophomonas maltophilia, Aeromonas salmonicida, Serratia marcescens, Bacillus sp., Bacillus cereus, Aeromonas hydrophila and Proteus mirabilis (Table 2). Only three fungal species, Cladosporium sp., Mucor sp. and Candida albicans were isolated from oral cavity samples (Table 3).

Table 3. Fungal species isolated from oral cavity and cloaca of four-lined snakes from islands Cres and Olib

\begin{tabular}{|c|c|c|}
\hline \multirow[b]{3}{*}{ Fungal species } & \multicolumn{2}{|c|}{ Number of positive findings in 10 animals from each island } \\
\hline & Cres & Olib \\
\hline & \multicolumn{2}{|c|}{ Oral cavity } \\
\hline Candida albicans & 2 & 1 \\
\hline Cladosporium sp. & 5 & $2^{\mathrm{B}}$ \\
\hline \multirow[t]{2}{*}{ Mucor sp. } & 2 & 3 \\
\hline & \multicolumn{2}{|c|}{ Cloaca } \\
\hline Aspergillus flavus & & 1 \\
\hline Aspergillus niger & 1 & \\
\hline Candida albicans & 1 & \\
\hline Rhodotorula rubra & 2 & \\
\hline Cladosporium sp. & & $1^{\mathrm{A}}$ \\
\hline Mucor sp. & 1 & \\
\hline
\end{tabular}

Different superscript letters indicate difference between oral cavity and cloaca of the whole group of animals; $\mathrm{P}=0.04$ (Fischer's exact test).

Ten bacterial species, mostly Gram-negative, were isolated from cloacal swabs: Bacillus sp., Escherichia coli, A. hydrophila, B. cereus, Proteus sp., Staphylococcus sp., Micrococcus luteus, S. maltophilia, S. marcescens and P. fluorescens (Table 2). Four fungal species were isolated from cloacal swabs: Rhodotorula rubra, Aspergillus niger, C. albicans and Mucor sp. (Table 3).

Island Olib. Bacterial flora in oral cavity of snakes from island Olib was also composed of Gram-positive and Gram-negative bacteria, with the predominance of Gram-negatives. Bacteria Bacillus sp., Staphylococcus sp. and A. salmonicida were present, as well as E. coli, P. fluorescens, M. luteus and S. maltophilia (Table 2). Three fungal species were isolated from oral cavity: Mucor sp., Cladosporium sp. and C. albicans (Table 3).

In cloacal swabs only four bacterial species were identified: Proteus sp., E. coli, Staphylococcus sp. and Bacillus sp. Proteus sp. was identified in significantly more, and 
Bacillus sp. in significantly less cloacal swabs than in Cres animals (Table 2). Two fungal species were isolated from cloacal swabs: Aspergillusflavus and Cladosporium sp. (Table 3).

All of the oral cavity and cloacal samples from both islands were negative for Salmonella spp. and Chlamydia spp.

\section{Discussion}

The four-lined snake (Elaphe quatuorlineata), the biggest European snake (KREINER, 2007), is strictly protected wild taxon in Croatia (ANONYMOUS, 2013) where it inhabits the whole littoral up to the altitude of $600 \mathrm{~m}$, and many islands.

From a total of 20 animals bacteria and/or fungi were isolated from oral cavity of eight snakes from each island. A total of 11 different bacterial species were identified, with a non-significant predominance of Gram-negatives. This finding is in line with the results of YAK et al. (2015) who isolated Gram-negative organisms from oral cavity of $8 / 10$ free-living reticulated pythons (Python reticulates) in Singapoore. No significant differences between two islands in the number or type of bacteria were noted. Most of the isolated Gram-negative, opportunistic microflora has already been described as a potential cause of diseases in animals and humans (DRAPER et al., 1981; HARRIS and ROGERS, 2001; CHEN et al., 2011). Considering an increasing popularity of reptiles in Croatia, this aspect of human infection should not be overlooked.

Cloacal bacteria were isolated from all of the animals studied. A total of 10 species were isolated, with predominance of Gram-negative ones, similarly to the situation in the oral cavity. In $50 \%$ of Cres and $60 \%$ of Olib animals E. coli was isolated, compared to $0 \%$ and $10 \%$ in the oral cavity, respectively. This significant difference indicates that, like in other animal species, the microflora along the snake gastrointestinal tract is different and does not have to be uniform in all of its segments. Significantly more cloacal swabs were positive to Bacillus sp. in Cres and to Proteus sp. in Olib animals. Both findings may indicate differences in geographic locations of particular snake populations regarding their oral cavity and cloacal aerobic microflora. However, the influence of potential Proteus sp. overgrowth due to longer-lasting transportation of samples from Olib than from Cres, should also not be excluded as a factor contributing to higher number of Proteus sp. isolates in Olib animals.

None of the samples in this study were positive to Salmonella sp., otherwise very frequent finding in snakes (KUROKI et al., 2013; SCHEELINGS et al., 2011; STING et al., 2013; LUKAC et al., 2015) and a common cause of disease in humans. Low incidence of Salmonella was also described by SCHMIDT et al. (2014) who reported 14.3\% (8/56) Salmonella spp. positive cloacal swabs in free-living snakes and lizards sampled in Germany. However, all of the animals in our study were sampled only once, so that one negative finding does not mean that animals were free of Salmonella, probably due to 
bacterial intermittent shedding (ACKMAN et al., 1995). Bacteria from Chlamydiaceae family, known to cause pneumonia (TAYLOR-BROWN et al., 2015) and hepatitis (HUCHZERMEYER et al., 2008) in reptiles, were also not detected in this study.

Three fungal species were isolated from oral cavity of snakes from both islands. The most frequent was Cladosporium sp. Although this is an ubiquitous organism, it was described as a cause of pneumonia in sea turtles (JACOBSON et al., 1979), nephritis and peritonitis in the loggerhead sea turtle (Caretta caretta) (DOMICIANO et al., 2014) and pneumonia in humans (METZGER et al., 2010). Opportunistic C. albicans was described as a cause of necrosis, bleeding and gastrointestinal edema in the Aldabra giant tortoise (Geochelone gigantea) (JUNIANTITO et al., 2009) and pulmonary candidiasis in spurthighed tortoise (Testudo greca) (HERNANDEZ-DIVERS, 2001). Although ENWEANI et al. (1997) described Candida spp. and Mucor spp. as normal isolates from gastrointestinal system of agamas, these fungi in combination with other microorganisms may cause ulcerative epidermitis (JACOBSON, 1980) and osteomyelitis (GARTRELL and HARE, 2005) in reptiles under suboptimal conditions.

Six fungal species were isolated from cloacal swabs of animals from both islands. Candida sp. and Aspergillus sp. were described as causes of secondary infections in gopher tortoise (Gopherus polyphemus) (MYERS et al., 2009) and both genera can cause various symptoms in humans, such as respiratory, intestinal or cutaneous problems, especially in immunocompromised people (BERNARDESCHI et al., 2015; NOBILE and JOHNSON, 2015). Rhodotorula rubra was reported to cause septicemia (EL-TAHAWY and KHALAF, 1999) and meningitis in immunocompromised persons (THAKUR et. al., 2007). There is no information on its effects in reptiles.

In conclusion, the results of this study indicate that four-lined snakes from Croatian islands Cres and Olib harbor numerous fungi as well as Gram-positive and Gram-negative bacteria, with some predomination of Gram-negative ones. Most of the isolated bacteria have already been described as causes of infection in both reptiles and humans. To the author's knowledge this is the first survey of oral cavity and cloacal aerobic microflora of four-lined snakes.

\section{References}

ACKMAN, D. M., P. DRABKIN, G. BIRKHEAD, P. CIESLAK (1995): Reptile associated salmonellosis in New York State. Pediatr. Infect. Dis. J. 14, 955-959.

ANONYMOUS (2013): Regulation on strictly protected species. Official Gazette of the Republic of Croatia 144/2013 (in Croatian).

BERNARDESCHI, C., F. FOULET, S. INGEN-HOUSZ-ORO, N. ORTONNE, K. SITBON, G. QUEREUX, O. LORTHOLARY, O. CHOSIDOW, S. BRETAGNE (2015): Cutaneous 
M. Lukač et al.: Oral and cloacal aerobic microflora of four-lined snakes (Elaphe quatuorlineata) from Croatia

Invasive Aspergillosis: Retrospective Multicenter Study of the French Invasive-Aspergillosis Registry and literature review. Medicine (Baltimore) 94, 1-9.

BROWN, A. E. (2005): Benson's Microbiological Applications: Laboratory Manual in General Microbiology. (Reidy, P. E., J. S. Fornango, Eds.) McGraw Hill, Inc., New York, USA.

CHEATWOOD, J. L., E. R. JACOBSON, P. G. MAY, T. M. FARELL, B. L. HOMER, D. A. SAMUELSON, J. W. KIMBROUGH (2003): An outbreak of fungal dermatitis and stomatitis in a free-ranging population of pigmy rattlesnakes (Sistrurus miliarius barbouri) in Florida. J. Wildl. Dis. 39, 329-337.

CHEN, C. M., K. G. WU, C. J. CHEN, C. M. WANG (2011): Bacterial infection in association with snakebite: A 10-year experience in a northern Taiwan medical center. J. Microbiol. Immunol. Infect. 44, 456-460.

DEKKER, J. P., K. M. FRANK (2015): Salmonella, Shigella and Yersinia. Clin. Lab. Med. 35, 225-246.

DiPINETO, L., T. P. RUSSO, M. CALABRIA, L. DE ROSA, M. CAPASSO, L. F. MENNA, L. BORRELLI, A. FIORETTI (2014): Oral flora of Python regius kept as pets. Lett. Appl. Microbiol. 58, 462-465.

DOMiCIANO, I. G., C. DOMIT, C. C. TRIGO, B. K. DE AlCANTARA, S. A. HEADLEY, A. P. BRACARENSE (2014): Phaeohyphomycoses in a free-ranging loggerhead turtle (Caretta caretta) from southern Brazil. Mycopathologia 178, 123-128.

DRAPER, C. S., R. D. WALKER, H. E. LAWER (1981): Patterns of oral bacterial infection in captive snakes. J. Am. Vet. Med. Assoc. 179, 1223-1226.

EHRICHT, R., P. SLICKERS, S. GOELLNER, H. HOTZEL, K. SACHSE (2006): Optimized DNA microarray assay allows detection and genotyping of single PCR-amplifiable target copies. Mol. Cell. Probes 20, 60-63.

EL-TAHAWY, A. T. A., R. M. F. KHALAF (1999): Rhodotorula rubra fungemia in an immunocompromised patient. Ann. Saudi Med. 19, 533-535.

ENWEANI, I. B., J. C. UWAJEH, C. S. BELLO, R. N. NDIP (1997): Fungal carriage in lizards. Mycoses 40, 115-117.

FOSTER, N., K. KERR (2005): The snake in the grass - Salmonella Arizonae gastroenteritis in a reptile handler. Acta Paediatr. 94, 1165-1166.

GARG, A., S. SUJATHA, J. GARG, N. S. ACHARYA, S. C. PARIJA (2009): Wound infections secondary to snakebite. J. Infect. Dev. Ctries. 3, 221-223.

GARTRELL, B. D., K. M. HARE (2005): Mycotic dermatitis with digital gangrene and osteomyelitis, and protozoal intestinal parasitism in Marlborough green geckos (Naultinus manukanus). New Zeal. Vet. J. 53, 363-367.

HABIB, A. G. (2002): Tetanus complicating snakebite in northern Nigeria: clinical presentation and public health implications. Acta Trop. 85, 87-91. 
M. Lukač et al.: Oral and cloacal aerobic microflora of four-lined snakes (Elaphe quatuorlineata) from Croatia

HARRIS, N. B., D. G. ROGERS (2001): Septicemia associated with Stenotrophomonas maltophilia in a West African dwarf crocodile (Osteolaemus tetraspis subsp. tetraspis). J. Vet. Diagn. Invest. 13, 255-258.

HERNANDEZ-DIVERS, S. J. (2001): Pulmonary candidiasis caused by Candida albicans in a Greek tortoise (Testudo graeca) and treatment with intrapulmonary Amphotericin B. J. Zoo Wildl. Med. 32, 352-359.

HUCHZERMEYER, F. W., E. LANGELET, J. F. PUTTERILL (2008): An outbreak of chlamydiosis in farmed Indopacific crocodiles (Crocodylus porosus). J. S. Afr. Vet. Assoc. 79, 99-100.

JACOBSON, E. R., J. M. GASKIN, R. P. SHIELDS, F. H. WHITE (1979): Mycotic pneumonia in mariculture-reared green sea turtles. J. Am. Vet. Med. Assoc. 175, 929-933.

JACOBSON, E. R. (1980): Necrotizing mycotic dermatitis in snakes: clinical and pathologic features. J. Am. Vet. Med. Assoc. 177, 838-841.

JHO, Y. S., D. H. PARK, J. H. LEE, S. Y. CHA, J. S. HAN (2011): Identification of bacteria from the oral cavity and cloaca of snakes imported from Vietnam. Lab. Anim. Res. 27, 213-217.

JUNIANTITO, V., T. IZAWA, M. KUWAMURA, M. YONEZAWA, S. ITO, J. YAMATE (2009): Gastrointestinal candidiasis in an Aldabra giant tortoise (Geochelone gigantea). J. Vet. Med. Sci. 71, 1269-1272.

KREINER, G. (2007): Colubridae. In: The snakes of Europe. (Kreiner, G., Ed.). Edition Chimaira, Frankfurt am Main. pp. 53-183.

KUROKI, T., T. ISHIHARA, I. FURUKAWA, A. T. OKATANI, Y. KATO (2013): Prevalence of Salmonella in wild snakes in Japan. Jpn. J. Infect. Dis. 66, 295-298.

LIU, P. Y., Z. Y. SHI, C. F. LIN, J. A. HUANG, J. W. LIU, K. W. CHAN, K. C. TUNG (2012): Shewanella infection of snakebites: a twelve-year retrospective study. Clinics (Sao Paulo) 67, 431-435.

LUKAC, M., K. PEDERSEN, E. PRUKNER-RADOVCIC (2015): Prevalence of Salmonella in captive reptiles from Croatia. J. Zoo Wildl. Med. 46, 234-240.

METZGER, F., A. HACCURIA, G. REBOUX, N. NOLARD, J. C. DALPHIN, P. De VUYST (2010): Hypersensitivity pneumonitis due to molds in a saxophone player. Chest 138, 724-726.

MILLER, D. L., Z. A. RADI, S. L. STIVER, T. D. THORNHILL (2004): Cutaneous and pulmonary mycosis in green anaconda (Euncectes murinus). J. Zoo Wildl. Med. 35, 557-561.

MYERS, D. A., R. ISAZA, G. BEN-SHLOMO, J. ABBOTT, C. E. PLUMMER (2009): Fungal keratitis in a gopher tortoise (Gopherus polyphemus). J. Zoo Wildl. Med. 40, 579-582.

NICHOLS, D. K., R. S. WEYANT, E. W. LAMIRANDE, L. SIGLER, R. T. MASON (1999): Fatal mycotic dermatitis in captive brown tree snakes (Boiga irregularis). J. Zoo Wildl. Med. 30, 111-118.

NOBILE, C. J., A. D. JOHNSON (2015): Candida albicans biofilms and human disease. Ann. Rev. Microbiol. 69, 71-92.

ORÓS, J., A. ARENCIBIA, L. FERNÁNDEZ, H. E. JENSEN (2004): Intestinal candidiasis in a loggerhead sea turtle (Caretta caretta): an immunohistochemical study. Vet. J. 167, 202-207. 
M. Lukač et al.: Oral and cloacal aerobic microflora of four-lined snakes (Elaphe quatuorlineata) from Croatia

RABINOWITZ, P. M., Z. GORDON, L. ODOFIN (2007): Pet-related infections. Am. Fam. Physician 76, 1314-1322.

ROSENTHAL, K. L., D. R. MADER (1996): Microbiology. In: Reptile Medicine and Surgery. (Mader, D. R. Ed.). W.B. Saunders Co., Philadelphia, Pennsylvania. pp. 117-125.

SCHEELINGS, T. F., D. LIGHTFOOT, P. HOLZ (2011): Prevalence of Salmonella in Australian reptiles. J. Wildl. Dis. 47, 1-11.

SCHMIDT, V., R. MOCK, E. BURGKHARDT, A. JUNGHANNS, F. ORTLIEB, I. SZABO, R. MARSCHANG, I. BLINDOW, M. E. KRATUWALD-JUNGHANNS (2014): Cloacal aerobic bacterial flora in free-living slow worms (Anguis fragilis), grass snakes (Natrix natrix) and European adders (Vipera berus) from Germany. EcoHealth 11, 571-580.

STING, R., D. ACKERMANN, B. BLAZEV, W. RABSCH, I. SZABO (2013): Salmonella infections in reptiles - prevalence, serovar spectrum and impact on animal health. Berl. Münch. Tierärztl. Wochenschr. 126, 202-208.

TAYLOR-BROWN, A., S. RÜEGGS, A. POLKINGHORNE, N. BOREL (2015): Characterisation of Chlamydia pneumoniae and other novel chlamydial infections in captive snakes. Vet. Microbiol. 178, 88-93.

THAKUR, K., G. SINGH, S. AGARWAL, L. RANI (2007): Meningitis caused by Rhodotorula rubra in an human immunodeficiency virus infected patient. Indian J. Med. Microbiol. 25, 166-168.

YAK, R., A. C. LUNDIN, P. Y. PIN, S. J. SEBASTIN (2015): Oral bacterial microflora of freeliving reticulated pythons (Python reticulatus) in Singapore. J. Herpetol. Med. Surg. 25, 40-44.

Received: 16 December 2015

Accepted: 1 August 2016

\section{LUKAČ, M., D. HORVATEK TOMIĆ, Z. MANDAC, S. MIHOKOVIĆ, E. PRUKNER-RADOVČIĆ: Aerobna bakterijska i gljivična flora usne šupljine i kloake kravosasa (Elaphe quatuorlineata) u Hrvatskoj. Vet. arhiv 87, 351-361, 2017. SAŽETAK}

Bakterijske i gljivične bolesti dobro su poznat problem gmazova u zatočeništvu. Mnogo je manje podataka dostupno o fiziološkoj flori probavnog sustava i mogućim patogenima divljih gmazova. Svrha je ovog istraživanja bila identificirati aerobnu floru usne šupljine i kloake kravosasa (Elaphe quatuorlineata) s hrvatskih otoka Cresa i Oliba, kako bi se saznalo više o bakterijama i gljivicama koje pod nepovoljnim okolnostima mogu uzrokovati bolest u samih životinja ali i u ljudi koji dolaze u kontakt s tim životinjama. Uzeti su obrisci usne šupljine i kloake od ukupno 20 kravosasa i analizirani standardnim mikrobiološkim metodama, te metodom realtime PCR za dokazivanje bakterija Chlamydia spp. U uzorcima nisu bile dokazane ni salmonele ni klamidije, no izdvojene su neke bakterije poznate kao mogući patogeni u čovjeka, poput vrsta Aeromonas hydrophila, Escherichia coli, Serratia marcescens i Stenotrophomonas maltophilia. Izdvojene su i neke gljivice, poput vrsta Candida albicans, Aspergillus flavus i Cladosporium sp., koje su već opisane kao sekundarni uzročnici bolesti u kolekcijama gmazova. Prema saznanjima autora, ovo je prvo istraživanje aerobne mikroflore kravosasa.

Ključne riječi: kravosasi, usna šupljina, kloaka, bakterije, gljivice 
